\title{
An Investigation on Effects of Certificates To Corporate Structure Of Enterprises In Civil Aviation Sector ${ }^{1}$
}

\author{
Sabiha ANNAÇ GÖV \\ Assist. Prof, Gaziantep University, \\ Faculty of Aviation and Astronautics, Department of Aviation Management \\ sgov@gantep.edu.tr \\ Orcid ID: https://orcid.org/0000-0001-7601-559X

\section{H. Mustafa PAKSOY} \\ Prof. Dr., Gaziantep University, \\ Faculty of Economics and Administrative Sciences, Department of Business \\ Administration \\ hmpaksoy@gantep.edu.tr \\ Orcid ID: https://orcid.org/0000-0002-6852-8659
}

\begin{abstract}
Certification legislation in the aviation sector is determined and carried out by national and international authorities. Civil aviation enterprises have to comply with the standards of these authorities due to their institutional structure. In addition to being affected legally and technically in the process of compliance with the certification legislation; aviation enterprises are also affected by the institutional aspect. The aim of this research is to reveal the effects of certification studies on the institutional structures of enterprises by using a survey method. It is examined whether national and international certification standards which are shaping the civil aviation sector in Turkey affect the corporate structure or not by developing special scale. In the study, a survey was applied to 112 enterprises in the aviation sector and the data were analysed in SPSS statistical program. It has been determined that the requirements of the certification affect the corporate identity of the enterprises, the organizational structure components such as the organizational structure, quality management systems of the organizations, It was determined that corporate social responsibility traditions were not affected by the certification requirements.
\end{abstract}

\footnotetext{
${ }^{1}$ Article Arrival/Acceptance Date: 05.05.2021 / 02.08 .2021

Reference Information: Annaç Göv, S. and Paksoy, H.M. (2021). An Investigation on effects of certificates to corporate structure of enterprises in civil aviation sector. Kahramanmaraş Sütçü İmam University Journal of Social Sciences, 18(2), 1218-1246. DOI: $10.33437 /$ ksusbd.933378
} 


\section{S.Annac Göv-H.M.Paksoy An Investigation on Effects of Certificates...}

Keywords: Certification, Licensing, Aviation, Corporate Structure, İnstitutionalization.

\section{Sivil Havacılık Sektöründe Sertifikaların İşletmelerin Kurumsal Yapılarına Etkileri Üzerine Bir Araştırma}

\section{Öz}

Havacılık sektöründe sertifikasyon mevzuatları ulusal ve uluslararası otoriteler tarafından belirlenmekte ve yürütülmektedir. Sivil havacilık işletmelerinin kurumsal yapıları gereği bu otoritelerin standartlarına uyması gerekmektedir. Havacılık işletmeleri sertifikasyon mevzuatlarına uyum sağlama sürecinde hukuki ve teknolojik açıdan etkilenmelerinin yanı sıra, kurumsal açıdan da bu süreçten etkilenmektedirler. $\mathrm{Bu}$ araștırmanın amacı sertifikasyon çalışmalarının işletmelerin kurumsal yapılarına etkilerini anket yöntemi kullanarak ayrıntılı bir biçimde ortaya koymaktır. Çalışmada Türkiye'deki sivil havacılık sektörünü şekillendiren ulusal ve uluslararası standartların ve sertifikaların işletmelerin kurumsal yapılarına etkileri özel ölçek geliştirilerek incelenmiştir. Araştırmada havacılık sektöründeki 112 işletmeye anket uygulanmış ve veriler SPSS istatistik programında analiz edilmiştir. Sertifikasyon gereklerinin işletmelerin kurumsal kimliklerini, yönetim organizasyon yapılarını, kalite yönetim sistemleri gibi kurumsal yapı bileşenlerini etkilediği tespit edilmiştir. Kurumsal sosyal sorumluluk geleneklerinin ise sertifika gereklerinden etkilenmediği belirlenmiştir..

Anahtar Kelimeler: Sertifikasyon, Lisans, Havacılık, Kurumsal Yap1, Kurumsallaşma.

\section{INTRODUCTION}

The rapid technological developments, which are characteristic of our age, accelerate the lives of people. The aviation sector also has its share in this rapid development. Interest in the aviation sector is increasing. Now the share of the airways in transportation is reaching the level of transport on the roads and the sea. New aircraft (airplanes, helicopters, balloons, etc.) are continuously being made with the latest technology to meet the growing demand in the sector. Therefore Airway traffic is gaining intensity. This intensity brings along the security problem. Factors such as air safety, comfort and speed are even more important. International aviation authorities, which set the limits of these factors, set standards in the sector. International aviation authorities are located in two locations, namely America (FAA: Federal Aviation Administration) and Europe (EASA: European Aviation Safety Agency) (EASA, 2014). Also ICAO 
(International Civil Aviation Organization) is a specialized and funding agency of the United Nations. It changes the principles and techniques of international air navigation and fosters the planning and development of international air transport to ensure safe and orderly growth. ICAO has got 18 annexes which are for some certifications.

In Turkey, the Directorate General of Civil Aviation (DGCA), has been helping businesses in making the company certificate and fit for the standards set by these authorities. Certificates specifying the standards that airway operators must comply with and the rules which determine the rules that should be complied with in terms of airworthiness of aircraft producing enterprises (Kenaroğlu, 2011) affect the institutional structures of enterprises. In other words, certification is affecting the corporate structure of the organization such as the parameters that organizational culture, human resources, working conditions. The effects of the certifications to the institutional structure are discussed in this study.

The aviation sector consists of sub-sectors such as airline, airport, balloon, maintenance repair, air taxi, ground services, and flight training organizations. Every business in the industry has to comply with the specific standards and certificates that document these standards are available. The certificates in the civil aviation sector can be classified as follows: Airline operating certificate, air taxi operation certificate, maintenance business certification, ground handling services certificate, heliport operation certificate, certificate of the enterprises that train human resources in aviation industry (pilot, hostess etc. license), aircraft certificate (type , airworthiness, noise, etc.).

The certificate is an official document that states that the information on it is true, and that is given to someone as proof that they are, have, or own something, or have permission to do something (TDK, 1988). Certification is defined "Formal procedure by which an accredited or authorized person or agency assesses and verifies (and attests in writing by issuing a certificate) the attributes, characteristics, quality, qualification, or status of individuals or organizations, goods or services, procedures or processes, or events or situations, in accordance with established requirements or standards.” (Businessdictionary, 2018).

Enterprises, no matter which sector, have their own standards, certificates, licenses, or work permits indicating that they are in compliance with the standards. In the aviation sector, the rules are much clearer and more precise than in other sectors. For example, there are rules and instructions that an entity has to comply with in order to be an airline operator, that is, to obtain airline operating certificates. "Aviation rules are written in blood." The word states that the rules are formed by living and taking lessons via accidents. The importance of the rules in the aviation sector can be understood from the abundance of standards and 


\section{S.Annac Göv-H.M.Paksoy An Investigation on Effects of Certificates...}

certificates in the sector. Businesses have to take into account standard and certificate requirements when creating their corporate structures.

Turkey has worked with hundreds of relevant ISO standards but has not yet received a study on certification in the aviation sector. This research is important in terms of being the first and only in Turkey. The effects of these standards on the corporate structure of the enterprises and their results will contribute to the literature. The aim of this study is to introduce the aviation sector and to understand the corporate (institutional) structure and to examine the certification activities in the sector and to reveal the effects on the corporate structure.

\section{LITERATURE REVIEW}

The human being who has been living as a social being since the day of his existence; In the economic, social, legal and political spheres, there have been numerous institutions that affect life. These formations gained different developmental dimensions in the last century (management-organization thought, inter-institutional relations). The definition of the concept of the corporate (institution), which is mostly sociologically done, raises the norms and values of the institutions (Ganesh, 1980). It is known as institution, establishment or facility with the most general definition of the institution of the Turkish Language Institution. Legal definitions are also known as family, property, and marriage (TDK, 1988). As an example of the institution we can show; concepts such as military service, insurance, academic life, school, and voting can be different in itself. While some of the samples emphasize the concept of an organization, some of them emphasize structural or cultural contents. Although there are differences between these terms, there are common features that can be evaluated within the concept of the institution (Jepperson, 1991:144).

The concept of institution, which is closer to the concept of an organization, is defined as the organizations that make behavioral patterns and norm relations according to Etzioni, which provide the implementation, protection and establish valuable tasks and services in their environment (Ganesh, 1980: 210).

It is possible to examine the concept of the institution in two parts. The first is the main rules. They express sociologically evolved values and norms. Institutions such as professional ethics and human rights are examples of the main institutions. It is not possible to replace the main institutions easily. The secondary institutions, which are a sub-branch of the main institutions, which include agreements, laws, organizations and organizational rules, can be considered as a sub-branch of the main institutions that aim to solve some sociological problems. Secondary institutions are more flexible and easier to modify than the main institutions (Bresser \& Millonig, 2003: 222). The 
association studies between the concepts of institutionalism and organizations started in the 1940s and settled on the ground in the 1990s (Scott, 2013: 21).

The organizations formed by individuals and individuals are surrounded by a network of values, rules, norms, patterns of behavior and beliefs, and a network that shapes their actions (Hasselbladh \& Kallinikos, 2000: 698). In general, institutionalism can be defined as the relations between formal organizational structures and social processes that contribute to the development of these organizations (Dillard, Rigsby, \& Goodman, 2004: 508).

When you say 'institution', the organizational structure of an enterprise, organizational culture, and management structure come to mind, that is, the concept of corporate structure includes organization, coordination, human resources, financial structure, culture, and relations with the internal and external environment, strategies and self-revealing identity. If the concept of institutional structure is taken on the basis of enterprises, the organizational structure comes to mind. Corporate identity (mission, vision), characteristics, corporate governance, strategic management, corporate social responsibility, management functions (planning, organization, human resources, auditing, financial management, reporting) constitute the components of the corporate structure.

The corporate identity is; all methods and materials applied in order to meet the determined corporate objectives, to have the desired prestige and to introduce the corporate philosophy to its partners and society. In this process, it is necessary to convey the visual and non-visual activities of the institution in its own form to the target groups. The materials used by the institution in communicating with the main mass should be carefully selected (İzzet, 2004: 111; Okay, 2000: 74; Uzoğlu, 2001: 341). Corporate behavior, corporate culture, corporate image, corporate communication, and corporate philosophy constitute the elements of corporate identity.

Corporate identity concept can be defined "The existence of a system of characteristics which has a pattern which gives the company its specificity, its stability and its coherence" They emphasize that it is the pattern or combination, not the characteristics themselves, which constitutes the identity of the organization (Moingeon \& Ramanantsoa, 1995: 253).

(Balmer \& Soenen, 1998) propose an organically inspired new corporate identity mix as being composed of the mind, soul, and voice. The mind consists of the managerial vision, corporate philosophy, strategy, performance, brand architecture, nature of corporate ownership, and organizational history. The soul consists of the subjective elements including the distinct values, a mix of subcultures, employee affinities, and internal images. 


\section{S.Annaç Göv-H.M.Paksoy An Investigation on Effects of Certificates...}

Corporate behavior; It can be defined as a concept which consists of selfformed, corporate culture, planned, institutional integrity. The corporate culture that expresses the form of the organization, the value judgments affecting the employees and the behavioral system; briefly, it can be defined as beliefs, values, and behaviors shared by a company (Okay, 2000).

In order to establish corporate philosophy, the institution should use effective communication tools and seek answers to the main problems that will determine the process. In this context, concepts such as corporate mission and corporate vision can be considered as an important component of corporate philosophy. The determination of the corporate philosophy is very important in terms of understanding the reason for the existence of the institution and the goals it wants to reach. The differences between these institutional philosophies allow the determination of differences between institutions (Uzoğlu, 2001: 341).

The corporate image, which is revealed and fed by the past experiences of the institution, can be defined as the outward reflection of its present image. The corporate image defined as the whole of the behaviors, attitudes, and beliefs that suggest the institution; corporate communication, corporate appearance, and corporate behavior. Corporate image is to create trust on the external and internal target audiences, to provide credibility and to ensure the continuity of trust (Dowling, 1993: 21).

Corporate communication is divided into two as internal and external communications. The communication and interaction of the employees of the institution are called internal communication; the interaction between the institution and the target group and other institutions and organizational structures is called external communication. Effective and successful internal and external communication can affect the corporate image and corporate success positively (Okay, 2000: 175).

Corporate culture; It can be defined as a set of practices and symbols consisting of behaviors, norms, values, habits and beliefs that are formed as a result of traditional, feeling, thinking and reacting actions that characterize and shape common denominators, their acceptance and behaviors with the institution or its members (Ak, 1998: 88; Goffee \& Jones, 2002: 35).

Corporate governance defined as the system in which the institutions are controlled and directed; corporate governance is a series of interactions and relationships between organizations and other organizations that have interests. Corporate governance, which sets the objectives and objectives of the institution, sets forth the methods to be followed in order to reach the targets (Menteş, 2009). Depending on the type of corporate governance and management style, the direction and performance of the organization may change according to the 
hierarchy and shareholding among employees. The realization of these orientations within the institution in the same direction may increase the success and efficiency of the institution. The management staff of the organization aims to reduce misleading and misinformation sources and aim to increase the efficiency of the institution in the commercial environment and increase its efficiency. In the case of healthy production and transfer of information, the efficiency of the institution can be increased by decreasing the undesirable costs (Deloitte, 2007).

Institutionalization aims to make the institutional structure suitable for the purposes, to define the job and job descriptions, to create internal regulations, to share responsibilities and authorities and to become professional. It aims at a systematic operation that does not leave the continuity of the institution dependent on individuals. In this process, the development of ownership and control concepts can be defined as corporate governance. In achieving a determined goal; the business must have the management of an organization, the determination and administration of internal and external interactions and the management of the effects of these interactions should be expressed. (Sönmez \& Toksoy, 2011);

Strategic management is an important concept that determines the objectives and future objectives of the organizations and organizes their activities to achieve these goals. This is a process composed of four concepts as mission, vision, tactics, and strategy (Boseman, Phatak, \& Schellenberger, 1989; Leskinen, Leskinen, Kurttila, Kangas, \& Kajanus, 2006). It can be explained that to realize the goals and objectives is vision; assignments in line with corporate decisions and objectives is mission; to implement strategies for achieving the goal is tactical concepts (Hitt MA \& Hoskissoti, 1995). In order to ensure that the institutions realize their future goals, the organization's current situation analysis should be done well, the weaknesses and strengths of the institution should be determined and the probable threats should be studied and analyzed correctly (Greer, 2001). In the planning of these targets, appropriate strategies should be developed by determining environmental diagnostics and future forecasts in strategic planning (Dinçer, 1992; Wilson, 1994). A sustainable strategy should be developed between the organization's strategic objectives and its relationship with the market (Dalay, Coşkun, \& Altunışık, 2002; Thompson Jr, 1996).. Strategic management planning can be considered as a solution to the problem of reaching an organization's objectives (Ülgen \& Mirze, 2007)

We can describe the corporate performance scorecard as a reporting of traditional measurement methods that help and solve the problems, they face in order to increase the success of their organizations and to facilitate their achievement. In this process, management approaches such as total quality, 


\section{S.Annac Göv-H.M.Paksoy An Investigation on Effects of Certificates...}

quality assurance, customer-centered production, process management, change management, competition management are affected (Brander Brown \& McDonnell, 1995). By using the institutional performance scorecard, the organization's strategy can be determined by the interactions between the institution's long and short term goals, results and performances, in line with the cause and effect relationship. (Kaplan \& Norton, 2004: 54).

It is defined as corporate social responsibility by the fact that any institution exhibits responsible and ethical behaviors towards both its internal and external partners and applying decisions in this direction (Kayacan, 2005). The organization's production activities without affecting the environment and nature, without affecting the social structure, production in line with growth targets, the relationship with other institutions and the relationship with the partners can be considered as corporate social responsibility (Aktan \& Börü, 2007: 13).

Briefly, when we look at the literature, it is seen that there are many components related to the institutional identity and structure of the organization.

\section{METHODS, MODEL OF RESEARCH AND HYPOTHESES}

The aim of this study is to determine the effects of the certification process, which provides compliance with the international aviation standards, on the institutional structures of enterprises.

The survey method was used as the data collection method and the questionnaire forms were prepared by using the researches in the related literature. The research scale was formed by authors. The survey questions are designed to determine the effects of the certification process on the institutional structures of the enterprises. The questionnaire consisted of three parts and in the first part the demographic characteristics of the participants; in the second part, 28 statements aimed at determining the impact of the certification process on the institutional structure of enterprises; and in the third chapter, 12 statements are given to determine the extent to which certification studies affect the institutionalization process. These data were analyzed by descriptive statistical analysis and multivariate statistical analysis. The research models are given figure 1 and figure 2 .

People tend to choose the most negative or the most positive option when faced with a two-grade option, such as 1950 I agree - I totally agreed or, I do not approve (Cronbach, 1950). In this study, a pilot study has been done and the answers are concentrated in the options 1: disagree, 2: partially agree, 3: agree. Therefore, the main study questionnaire was prepared with 3 options. 
The universe of the research consists of 179 aviation enterprises, 47 ground handling operations, 54 maintenance, and 46 training facilities and a total of 326 enterprises. The survey created for the study was made available on Google form. The questionnaire was sent as a link to the individuals in the relevant enterprises between 10.04.2015-30.07.2015. The questionnaires answered were taken into consideration and the data obtained were analyzed. As the whole of the population could not be reached in the study, the sample selection was made and a questionnaire form was sent to the employees in the 120 enterprises selected by the sampling method. 8 questionnaire forms which are defective and incomplete were canceled and 112 people were obtained and the data collection process was completed because the sample was found sufficient to represent the universe.

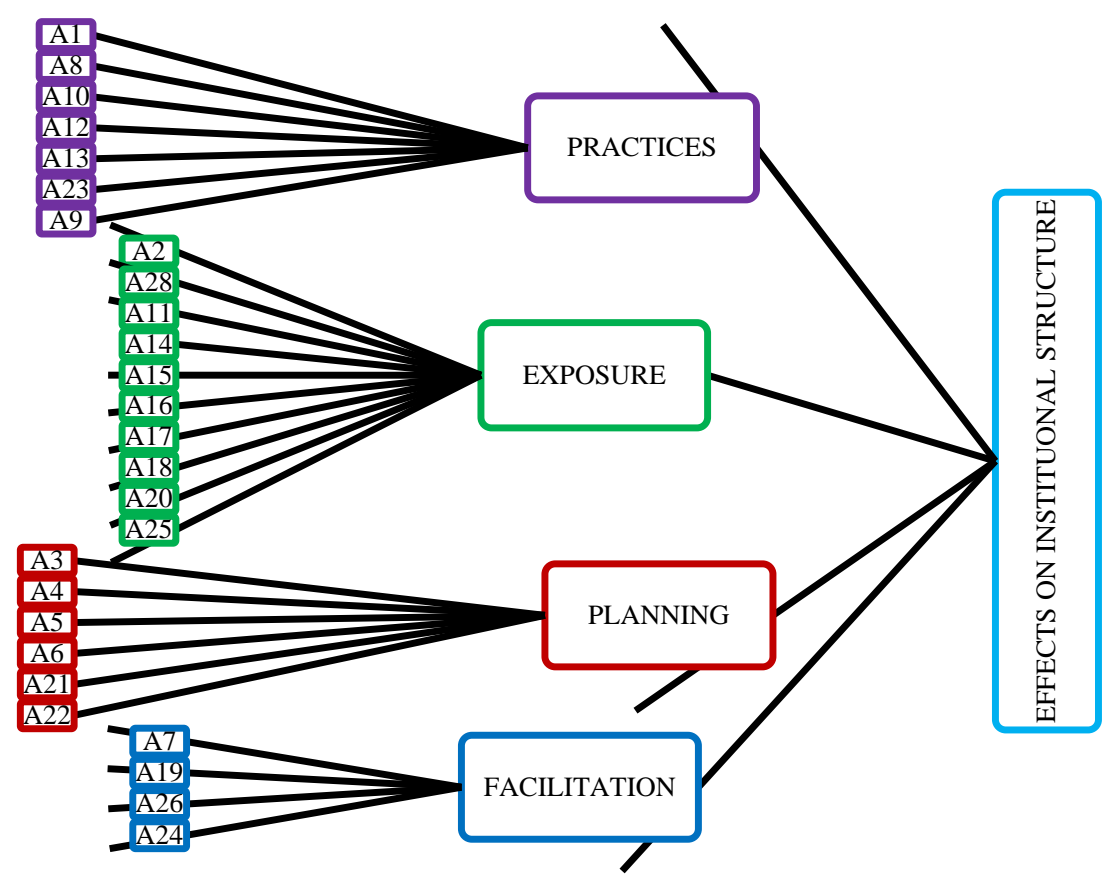

Figure 1. The Institutional Structure Research Model 


\section{S.Annac Göv-H.M.Paksoy An Investigation on Effects of Certificates...}

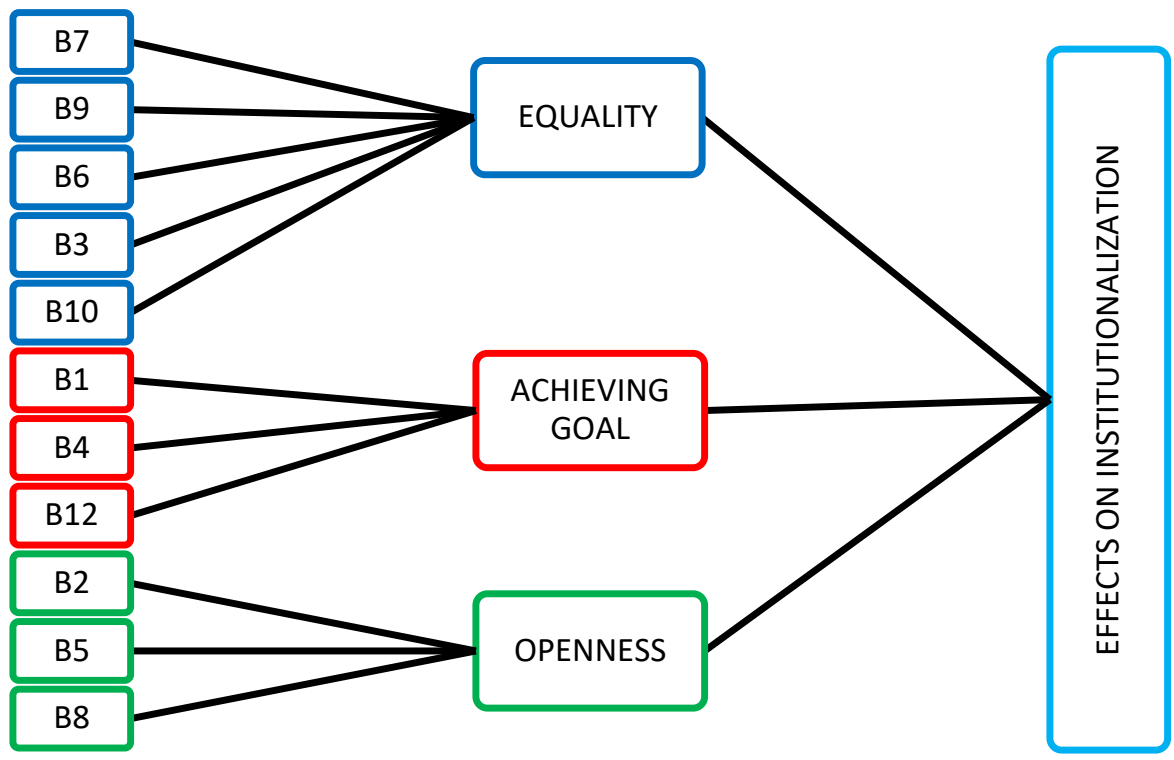

Figure 2. Institutionalization Research Model

Research hypotheses are as follows;

H1: There is a difference in the point of view of institutionalization subdimensions according to the area where enterprises operate.

$\mathrm{H} 2$ : According to the legal structure of enterprises, there are differences in the view of institutionalization sub-dimensions.

H3: According to the task in the enterprise, there are differences in the view of institutionalization sub-dimensions.

\section{RESULTS}

The data obtained in the research are shown as frequency, percentage, arithmetic mean, standard deviation according to the questions and subject area. The desired method of analysis is 5-point Likert, but the answers given in the pilot study were mainly focused on 3 basic options, and the questionnaire was applied as three-choice. The options determined as 'Agree', 'Partially Agree' and 'I disagree' were scored according to the number of levels in the form of 3, 2, and 1.

Factor analysis was applied to the statements related to the impact of the certification studies on the institutionalization process of the participants; Anova analyzes were performed in order to determine whether the views of the sub- 
dimensions obtained as a result of the applied factor analysis differ or not, and the correlation analysis was performed in order to determine the relationship between the factors.

\section{Demographic Characteristics of Participants}

The demographic characteristics of the participants and the frequency percentage of their answers to their questions are given in the table below. In the survey study, the participants were asked the question 'Which area do you mainly operate in the aviation industry' and the statistical analysis results are given in Table 1.

Table 1. Businesses Operating In the Aviation Industry

\begin{tabular}{|l|c|c|}
\hline & Frequency & Percent \\
\hline Airline business & 11 & 9,8 \\
\hline Air taxi business & 12 & 10,7 \\
\hline General aviation business & 12 & 10,7 \\
\hline Ground handling services & 4 & 3,6 \\
\hline Maintenance and repair business & 52 & 46,4 \\
\hline Aviation training facility & 8 & 7,1 \\
\hline Heliport business & 3 & 2,7 \\
\hline Aviation Club & 10 & 8,9 \\
\hline Total & 112 & 100 \\
\hline
\end{tabular}

Of the companies participating in the survey, 9.8\% were in airline operation, $46.4 \%$ in maintenance and repair, and $10.7 \%$ in general aviation operation, $10.7 \%$ in air taxi operation and $8.9 \%$ in aviation the club consists of people working in the business.

In the survey study, 'How many years has your organization been active?' and the results of statistical analysis are given in Table 2.

Table 2. Operating Periods of Aviation Enterprises

\begin{tabular}{|l|c|c|}
\hline & Frequency & Percent \\
\hline $1-5$ years & 33 & 29,5 \\
\hline $6-10$ years & 26 & 23,2 \\
\hline $10-15$ years & 14 & 12,5 \\
\hline 15 years and over & 39 & 34,8 \\
\hline Total & 112 & 100 \\
\hline
\end{tabular}




\section{S.Annac Göv-H.M.Paksoy An Investigation on Effects of Certificates...}

When the distribution of the institutions according to the duration of the activities is examined, it is seen that there are institutions operating in.34,8\% of the survey is more than 15 years, $29,5 \%$ is between $1-5$ years, $23,2 \%$ is between $6-10$ years and $12,5 \%$ is between $10-15$ years.

In the survey study, the participants were asked the question 'How many people work in your company?' and according to the answers, the results of the statistical analysis are given in Table 3.

Table 3. Number Of Personnel Of Aviation Enterprises

\begin{tabular}{|l|c|c|}
\hline & Frequency & Percent \\
\hline $1-9$ staffs & 25 & 22,3 \\
\hline $10-49$ staffs & 23 & 20,5 \\
\hline $50-249$ staffs & 14 & 12,5 \\
\hline 250 and over & 50 & 44,6 \\
\hline Total & 112 & 100 \\
\hline
\end{tabular}

Looking at the distribution of the number of employees of the participating institutions; In 50 institutions 250 and over, in 25 institutions 1-9, in 23 institutions 10-49 and in 14 institutions 50-249 staff are seen. According to these results, it is understood that the majority of the institutions participating in the research are big business status.

In the survey study, the participants were asked the question 'What is the legal structure of your business?' and according to answers, the results of the statistical analysis are given in Table 4.

Table 4. Legal Structures of Aviation Enterprises

\begin{tabular}{|l|c|c|}
\hline & Frequency & Percent \\
\hline Joint Stock Company & 65 & 58,4 \\
\hline Limited Liability Company & 8 & 7,1 \\
\hline Clubs, associations and other & 39 & 34,8 \\
\hline Total & 112 & 100 \\
\hline
\end{tabular}

According to the legal structure of the participating institutions, it is understood that $58.4 \%$ is a joint stock company, $34.8 \%$ is a club association and other enterprises and only $7.1 \%$ is a limited company. 
In the survey study, 'What is your duty in the enterprise?' were asked and according to the answers received; the results of statistical analysis are given in Table 5.

Table 5. Distribution of Personnel Duties of Aviation Enterprises

\begin{tabular}{|l|c|c|}
\hline & Frequency & Percent \\
\hline Owner & 27 & 24,1 \\
\hline General Manager & 12 & 10,7 \\
\hline Director of HRM & 38 & 33,9 \\
\hline Pilot & 17 & 15,2 \\
\hline Other & 18 & 16,1 \\
\hline Total & 112 & 100 \\
\hline
\end{tabular}

When the distribution of the tasks of the participants in their businesses is examined; it is seen that 38 participants are HR managers, 27 people are business owners, 17 people are pilots, 12 people are general managers and 18 people are working in other units (accounting, public relations, etc.)

\section{The Effects of The Certification Process On The Institutional Structure}

In the survey study, participants were asked the question of 'The Effects of the Certification Process on the Institutional Structure of Your Business' the results of statistical analysis are as below.

$54.5 \%$ of the participants stated that they agreed, and $12.5 \%$ of the participants stated that they had agreed partially to the statement of 'Our institution has contacted the DGCA during the certification process'. The average of the statement is 1.79 , and it can be considered that the participants mainly attended DGCA communication during the certification process. Similarly, $41,1 \%$ of the participants stated that they agree 'Certification studies increased their operating costs' statement and 30, 4\% stated that they agreed partially. Considering that the average of the statement is 1.88 , it can be said that the participants believe that certification studies increase the costs of enterprises.

91.1\% of the participants of the survey did not participate in the statement of "Planning of certification process was made in our institution" Considering that the average of the statement is 2, 82, it is understood that the participants did not believe in the planning process in the certification process. $85.7 \%$ of respondents did not participate statement of "Certification requirements provide a positive impact on customer relationship management." According to this result, the majority of participants do not believe that certification requirements have a positive effect on customer relationship management. $90.2 \%$ of the participants 


\section{S.Annac Göv-H.M.Paksoy An Investigation on Effects of Certificates...}

did not agree with the statement of "Financial planning was made for purchasing certificate." According to the average of the expression, the enterprises did not make financial planning in this process. Another remarkable point is that $89.3 \%$ of the participants stated that "Certificates had a positive impact on corporate performance.” Considering that the average of the statement is 2.89 , they believe that the certificates affect corporate performance positively.

According to the answers given to the expression of "Certificate, requirements accelerated your institutionalization process"; $55.4 \%$ of the participants agree, $43.8 \%$ of them participate partially, $0.9 \%$ said they did not participate. According to this result, participants had a positive impact on the level of certification requirements expected to accelerate the institutionalization process of their business.

\section{Factor Analysis of Certification Process and Reliability of The Scale}

The reliability analysis was performed to test the reliability of the research data before the factor analysis. The Cronbach's Alpha coefficient, which is used in the reliability analysis, shows that the scale is homogeneous and has a value between 0 and 1. Cronbach's Alpha coefficient should be greater than 0.60 in order for the scale used in the survey to be considered reliable (Kalayc1, 2014: 405). In the scale used in the research, the 27th expression 'Did the certificates affect sustainable environmental policies to protect natural life and prevent noise?' was excluded from the scale because it disrupted the factor structure and decreased its reliability. After this statement was taken, it was decided that the scale was acceptable in terms of reliability since Cronbach's Alpha coefficient of this scale was 0.806 .

After applying the reliability analysis to the data obtained from the study, factor analysis was applied to the data obtained as a result of responding to the developed qualification process scale in order to determine the dimensions of the certification studies affecting the institutionalization process. In order to determine the dimensions of the certification process, explanatory factor analysis was used. As a result of the factor analysis, the variables were tested by the Kaiser-Meyer-Olkin Measure (KMO) and Bartlett's whether the variables were suitable for factor analysis. The results of values has shown on Table 6 . 
Table 6. Factor Analysis of Certification Process

\begin{tabular}{|c|c|c|c|c|}
\hline & $\begin{array}{l}\text { Factor } \\
\text { Loads }\end{array}$ & \begin{tabular}{|c} 
Cron \\
bach' \\
s \\
Alph \\
a
\end{tabular} & \begin{tabular}{|c|} 
Core \\
value \\
$\mathrm{s}$
\end{tabular} & $\begin{array}{c}\text { Varian } \\
\text { ce }\end{array}$ \\
\hline Practices & & \multirow{8}{*}{0,957} & \multirow{8}{*}{79,076} & \multirow{8}{*}{32,415} \\
\hline $\begin{array}{l}\text { A1. Our corporate has conducted SWOT analysis } \\
\text { (strengths and weaknesses - opportunities and threats) in } \\
\text { this process. }\end{array}$ & 0,973 & & & \\
\hline $\begin{array}{l}\text { A8. Each step of the certification process was audited } \\
\text { internally. }\end{array}$ & 0,969 & & & \\
\hline A10. Benchmarking was done in certification prosess. & 0,969 & & & \\
\hline $\begin{array}{l}\text { A12. Our corporate has contacted ICAO or EASA } \\
\text { (European Aviation Security Agency) during the } \\
\text { certification process. }\end{array}$ & 0,951 & & & \\
\hline $\begin{array}{l}\text { A13. Our organization has contacted the DGCA during } \\
\text { the certification process. }\end{array}$ & 0,917 & & & \\
\hline $\begin{array}{l}\text { A23. Certificates made it necessary to train employees } \\
\text { continuously. }\end{array}$ & 0,884 & & & \\
\hline $\begin{array}{l}\text { A9. Outsourcing was conducted during the certification } \\
\text { process. }\end{array}$ & 0,604 & & & \\
\hline \multicolumn{2}{|l|}{ Exposure } & \multirow{10}{*}{0,679} & \multirow{10}{*}{5,924} & \multirow{10}{*}{21,157} \\
\hline $\begin{array}{l}\text { A2. Certification positively affected our corporate } \\
\text { identity (vision, mission, strategy). }\end{array}$ & 0,938 & & & \\
\hline $\begin{array}{l}\text { A28. There were organizational conflicts in the } \\
\text { certification process. }\end{array}$ & 0,934 & & & \\
\hline $\begin{array}{l}\text { A11. Our corporate experienced coordination problems } \\
\text { with the Directorate General of Civil Aviation, which is a } \\
\text { local aviation authority. }\end{array}$ & 0,883 & & & \\
\hline $\begin{array}{l}\text { A14. Certification requirements provide a positive impact } \\
\text { on customer relationship management. }\end{array}$ & 0,813 & & & \\
\hline $\begin{array}{l}\text { A15. Certificates positively impacted corporate } \\
\text { performance. }\end{array}$ & 0,811 & & & \\
\hline $\begin{array}{l}\text { A16. the certificate requirements affected our corporate } \\
\text { social responsibility policy. }\end{array}$ & $-0,739$ & & & \\
\hline $\begin{array}{l}\text { A17. Certificate requirements influenced our corporate } \\
\text { culture. }\end{array}$ & $-0,703$ & & & \\
\hline $\begin{array}{l}\text { A18. Certificate requirements influenced corporate } \\
\text { governance (fair, transparent, accountable, responsible) } \\
\text { dimensions in the financial field. }\end{array}$ & 0,679 & & & \\
\hline $\begin{array}{l}\text { A20. Certificate requirements affected the workflows of } \\
\text { the units in the business (personnel, financial affairs, } \\
\text { marketing, public relations, quality control, etc.). }\end{array}$ & $-0,631$ & & & \\
\hline
\end{tabular}


S.Annac Göv-H.M.Paksoy An Investigation on Effects of Certificates...

\begin{tabular}{|c|c|c|c|c|}
\hline A25. Certification work increased operating costs. & 0,591 & & & \\
\hline \multicolumn{2}{|l|}{ Planning } & \multirow{7}{*}{0,669} & \multirow{7}{*}{4,397} & \multirow{7}{*}{15,704} \\
\hline $\begin{array}{l}\text { A3. Certification process planning was made in our } \\
\text { institution. }\end{array}$ & 0,937 & & & \\
\hline $\begin{array}{l}\text { A4. Certifications determined our management and } \\
\text { organizational structure }\end{array}$ & 0,937 & & & \\
\hline $\begin{array}{l}\text { A5. Human resources were assigned for the certification } \\
\text { process in our institution. }\end{array}$ & 0,719 & & & \\
\hline A6. Financial planning was made for certification. & 0,703 & & & \\
\hline $\begin{array}{l}\text { A21. In-house job descriptions were determined } \\
\text { according to certificate requirements. }\end{array}$ & 0,687 & & & \\
\hline $\begin{array}{l}\text { A22. In-house rules were determined in accordance with } \\
\text { certificate requirements. }\end{array}$ & 0,612 & & & \\
\hline \multicolumn{2}{|l|}{ Facilitation } & \multirow{5}{*}{0,771} & \multirow{5}{*}{12,309} & \multirow{5}{*}{8,247} \\
\hline $\begin{array}{l}\text { A7. During the certification process, coordination among } \\
\text { the relevant units was ensured. }\end{array}$ & 0,992 & & & \\
\hline $\begin{array}{l}\text { A19. Certificate requirements have accelerated our } \\
\text { institutionalization process. }\end{array}$ & 0,879 & & & \\
\hline $\begin{array}{l}\text { A24. The certificate acquisition process made it easier for } \\
\text { the organization to establish a quality management } \\
\text { system. }\end{array}$ & 0,615 & & & \\
\hline $\begin{array}{l}\text { A26. Handbooks that the business should prepare } \\
\text { facilitated institutionalization. }\end{array}$ & $-0,518$ & & & \\
\hline Explained Variance & \multicolumn{4}{|c|}{77,523} \\
\hline $\begin{array}{l}\text { KMO (Kaiser-Meyer-Olkin Measure of Sampling } \\
\text { Adequacy.) }\end{array}$ & \multicolumn{4}{|c|}{0,837} \\
\hline Bartlett's Test of Sphericity & \multicolumn{4}{|c|}{ X2:2252,123; Sig (p): 0,000 } \\
\hline Cronbach's Alpha & \multicolumn{4}{|c|}{0,806} \\
\hline
\end{tabular}

\section{Dimensions of Influencing The Institutionalization Process of Certification Studies}

In the survey study, the participants were asked "Dimensions of influencing the institutionalization process of certification studies" and according to answers, statically analyses are as below.

According to the evaluation of the responses of the participants to the statements directed to the dimensions of the certification (license) studies affecting the institutionalization process; $25.9 \%$ of participants agreed that the expression of "the budget and business plans became clearer", $45.5 \%$ of them agreed partially and $28.6 \%$ stated that they did not agree. According to the 
answers of the participants, 9.8\% of them agreed that "Certificates increased corporate productivity (providing too much output with little input)", $58.9 \%$ of them partially participated, and $31.3 \%$ of them stated that they did not participate. Considering the average of the two expressions is 2.03 and 2.21, it can be interpreted that the participants in general agree.

For another statement directed to the participants that "Certification provided more regular and systematic work to the organization." $66.1 \%$ of the participants agreed, $33 \%$ of them agreed partially, and $0.9 \%$ of them did not agree. Considering the average of the answers given to the statement is 2, 6; It can be concluded that certification studies of the participants believe that their institutions provide a more regular and systematic working generally.

$66.1 \%$ of the participants agreed that "It made mandatory hiring qualified personnel." And 33.9\% of them agreed partially. Similarly, 88.4\% of participants stated that they agreed on the expression of "Ensuring the Control is easier." 10.7 $\%$ stated that they partially agreed and $0.9 \%$ did not agree. It is understood that the participants generally participated in the statements related to the impact of the institutionalization process on certification studies.

It is understood that the participants generally participated in the statements related to the impact of the institutionalization process on certification studies. The fact that they do not agree with some expressions except the statement of "It made mandatory hiring qualified personnel." cannot be interpreted as the fact that certification studies do not contribute positively to the institutionalization of enterprises. Answers to questions directly affecting institutionalization indicate that certification activities affect the institutional structure.

\section{Factor Analysis of Institutionalization Process}

The reliability analysis was performed to test the reliability of the research data before the factor analysis. The Cronbach's Alpha coefficient, which is used in the reliability analysis, shows that the scale is homogeneous and has a value between 0 and 1. Cronbach's Alpha coefficient should be greater than 0.60 in order for the scale used in the survey to be considered reliable (Kalayc1, 2014: 405).

The reliability analysis was conducted in order to test the reliability of the research data before the factor analysis. 11. Expression "Certificates increased institutional efficiency (providing too much output with little input” which is used in the scale was excluded from the scale because it disrupted the factor structure and decreased its reliability. After this statement was taken, it was decided that the scale was acceptable in terms of reliability since Cronbach's Alpha coefficient was 0,923 . 


\section{S.Annac Göv-H.M.Paksoy An Investigation on Effects of Certificates...}

After applying reliability analysis, descriptive factor analysis was used to determine the dimensions of the institutionalization process. As a result of factor analysis, the variables analyzed by Kaiser-Meyer-Olkin Measure (KMO) and Bartlett's tests were tested for the factor analysis of the analyzed variables. The values about these results are shown in Table 7

Table 7. Factor Analysis of Institutionalization Process

\begin{tabular}{|c|c|c|c|c|}
\hline Factors & & Cronb & & Varian \\
\hline First factor: Equality & Loads & $\begin{array}{c}\text { ach's } \\
\text { Alpha }\end{array}$ & Values & ce \\
\hline $\begin{array}{l}\text { B7.The certification process provided an } \\
\text { opportunity for employee participation. }\end{array}$ & 0,937 & \multirow{5}{*}{0,929} & \multirow{5}{*}{7,201} & \multirow{5}{*}{60,008} \\
\hline B9.The division of labor started to work healthier. & 0,810 & & & \\
\hline B6. Decisions are made easier. & 0,769 & & & \\
\hline B3. The error rate has dropped. & 0,655 & & & \\
\hline B10.It made mandatory hiring qualified personnel. & 0,611 & & & \\
\hline \multicolumn{2}{|l|}{ Second factor: Achieve goal } & \multirow{4}{*}{0,613} & \multirow{4}{*}{2,13} & \multirow{4}{*}{17,746} \\
\hline $\begin{array}{l}\text { B4. It made it easier for the organization to } \\
\text { achieve its goals. }\end{array}$ & 0,924 & & & \\
\hline B12.Increased corporate communication. & 0,767 & & & \\
\hline $\begin{array}{l}\text { B1. Certification provided more regular and } \\
\text { systematic work to the organization. }\end{array}$ & 0,653 & & & \\
\hline \multicolumn{2}{|l|}{ Third Factor: Openness } & \multirow{4}{*}{0,649} & \multirow{4}{*}{1,313} & \multirow{4}{*}{10,941} \\
\hline B5. Authority and responsibilities became clearer. & 0,888 & & & \\
\hline B2.Ensuring the Control is easier. & 0,698 & & & \\
\hline B8. Budget and business plans became more open. & 0,612 & & & \\
\hline Explained Variations & \multicolumn{4}{|c|}{88,695} \\
\hline $\begin{array}{l}\text { KMO (Kaiser-Meyer-Olkin Measure of sampling } \\
\text { adequacy.) }\end{array}$ & \multicolumn{4}{|c|}{0,737} \\
\hline Bartlett's Test of Sphericity & \multicolumn{4}{|c|}{$\mathrm{X}^{2}: 2302,155 ; \operatorname{Sig}(\mathrm{p}): 0,000$} \\
\hline Cronbach's Alpha & \multicolumn{4}{|c|}{0,923} \\
\hline
\end{tabular}

When the factor analysis results are analyzed; The KMO test value was found to be 0,737, Cronbach's Alpha 0,923, Bartlett test value 2302,155, $\mathrm{p}=0,000$. KMO test value greater than 0,60, Bartlett test value 2302,155, $p=0,000<0,05$ indicates that the data are suitable for factor analysis. As Cronbach's Alpha was found to be 0.923 , the scale had a high level of reliability.

It was observed that 12 items included in the scale of the effect of the institutionalization process of certification studies were collected under 3 factors. The sub-dimensions (factors) obtained from the factor analysis are called equality, goal-reaching, and openness. 


\section{Testing Hypotheses}

Anova analysis was used to test hypotheses, to test sub-hypotheses for differences in sub-dimensions, according to demographic characteristics; Correlation analysis was used to measure the relationships between subdimensions.

H1: According to the area where enterprises operate, there is a difference in the view of institutionalization sub-dimensions.

The hypothesis $\mathrm{H} 1$, in which institutionalization sub-dimensions are determined and tested according to the fields of activity of institutions, is given in Table 8.

Table 8. The Relationship Between The Field Of Activity And Institutionalization Sub-Dimensions

\begin{tabular}{|c|c|c|c|c|c|c|}
\hline & & $\mathbf{N}$ & Med. & S.D. & $\mathbf{F}$ & Sig. \\
\hline \multirow{8}{*}{ Equality } & Airline business & 18 & 2,79 & 0,39 & \multirow{8}{*}{7,16} & \multirow{8}{*}{0} \\
\hline & Air taxi business & 12 & 2,80 & 0,00 & & \\
\hline & General aviation business & 12 & 2,00 & 0,00 & & \\
\hline & Ground handling services & 4 & 3,00 & 0,00 & & \\
\hline & Maintenance repair business & 45 & 2,20 & 0,68 & & \\
\hline & Aviation training facility & 8 & 2,80 & 0,57 & & \\
\hline & Heliport business & 3 & 3,00 & 0,00 & & \\
\hline & Aviation club & 10 & 2,60 & 0,00 & & \\
\hline \multirow{8}{*}{ Achieving a goal } & Airline business & 18 & 2,83 & 0,30 & \multirow{8}{*}{22,90} & \multirow{8}{*}{0} \\
\hline & Air taxi business & 12 & 2,25 & 0,00 & & \\
\hline & General aviation business & 12 & 2,00 & 0,00 & & \\
\hline & Ground handling services & 4 & 3,00 & 0,00 & & \\
\hline & Maintenance repair business & 45 & 2,51 & 0,31 & & \\
\hline & Aviation training facility & 8 & 2,53 & 0,62 & & \\
\hline & Heliport business & 3 & 3,00 & 0,00 & & \\
\hline & Aviation club & 10 & 1,75 & 0,00 & & \\
\hline \multirow{8}{*}{ Openness } & Airline business & 18 & 2,83 & 0,29 & \multirow{8}{*}{23,04} & \multirow{8}{*}{0} \\
\hline & Air taxi business & 12 & 3,00 & 0,00 & & \\
\hline & General aviation business & 12 & 2,00 & 0,00 & & \\
\hline & Ground handling services & 4 & 3,00 & 0,00 & & \\
\hline & Maintenance repair business & 45 & 2,29 & 0,33 & & \\
\hline & Aviation training facility & 8 & 2,50 & 0,47 & & \\
\hline & Heliport business & 3 & 3,00 & 0,00 & & \\
\hline & Aviation club & 10 & 2,67 & 0,00 & & \\
\hline
\end{tabular}




\section{S.Annac Göv-H.M.Paksoy An Investigation on Effects of Certificates...}

Participants' equity scores, which are the sub-dimension of the institutionalization, were examined according to the field of activity. ANOVA analysis was performed to determine whether or not there was a significant difference. As a result, the p-value $(0.000<0.05)$ was statistically significant; the hypothesis $\mathrm{H}_{1 \mathrm{a}}$ "According to the field of activity, there is a difference in the view of equality which is the institutionalization sub-dimension" is accepted. As a result of the Tukey test conducted in order to determine the source of the difference, it has been determined that the area that creates the difference in the view of equality according to the area of activity is the enterprises operating in the field of airline operations and general aviation operation and maintenance and repair business.

Participants' achieving goal scores, which are the sub-dimension of the institutionalization, were examined according to the field of activity. ANOVA analysis was performed to determine whether or not there was a significant difference. As a result, the p-value $(0.000<0.05)$ was statistically significant; the hypothesis $\mathrm{H}_{\mathrm{b}}$ "According to the field of activity, there is a difference in the view of achieving the goal which is the institutionalization sub-dimension," is accepted. As a result of the Tukey test conducted in order to determine the source of the difference, it was determined that the area that created the difference in the view of achieving goal, according to the field of activity is the enterprises operating in the field of airline companies, air taxi operators, maintenance and repair facilities and aviation club.

The averages of the openness points which are the institutionalization subdimension of the participants were examined according to the field of activity. ANOVA analysis was performed to determine whether or not there was a significant difference; since the p-value $(0.000<0.05)$ is statistically significant, the hypothesis 'H1c: There is a difference in the view of openness which is the institutionalization sub-dimension according to the field of activity' is accepted. As a result of the Tukey test conducted in order to determine the source of the difference, it was determined that the area that created the difference in the view of openness was the airline companies, air taxi operators, maintenance and repair enterprises and the enterprises operating in the field of aviation education.

$\mathrm{H} 2$ : According to the legal structure of the enterprises studied, there is a difference in the view of institutionalization sub-dimensions.

According to the legal structures of institutions, the hypothesis of $\mathrm{H} 2$, in which institutionalization sub-dimensions are determined and tested, is given in Table 9.

Table 9. The Relationship Between Legal Structure And Institutionalization Sub-Dimension 


\begin{tabular}{|c|c|c|c|c|c|c|}
\hline & & $\mathbf{N}$ & Med. & S.D. & $\mathbf{F}$ & Sig. \\
\hline \multirow{3}{*}{ Equality } & Joint Stock Company & 65 & 2,38 & 0,64 & \multirow{3}{*}{4,33} & \multirow{3}{*}{0,02} \\
\hline & Limited Liability Company & 8 & 1,40 & 0,12 & & \\
\hline & Clubs, associations and other & 39 & 2,62 & 0,42 & & \\
\hline \multirow{3}{*}{ Achieving a goal } & Joint Stock Company & 65 & 2,51 & 0,33 & \multirow{3}{*}{7,65} & \multirow{3}{*}{0,00} \\
\hline & Limited Liability Company & 8 & 1,00 & 0,83 & & \\
\hline & Clubs, associations and other & 39 & 2,38 & 0,51 & & \\
\hline \multirow{3}{*}{ Openness } & Joint Stock Company & 65 & 2,53 & 0,45 & \multirow{3}{*}{4,21} & \multirow{3}{*}{0,02} \\
\hline & Limited Liability Company & 8 & 1,33 & 0,21 & & \\
\hline & Clubs, associations and other & 39 & 2,52 & 0,33 & & \\
\hline
\end{tabular}

Anova analysis was conducted to determine whether the averages of equality points, which are the institutionalization sub-dimensions of the participants, showed a significant difference according to the legal structure of their enterprises. As a result, the p-value $(0,02<0,05)$ was statistically significant and the hypothesis ' $\mathrm{H} 2_{\mathrm{a}}$ : According to the legal structures of the enterprises studied, there is a difference in the view of equality which is the institutionalization subdimension' was accepted. As a result of the Tukey test conducted to determine the source of the difference, it has been determined that there are joint stock companies, club associations and other enterprises that create the difference in the view of equality according to their legal structure.

ANOVA analysis was performed in order to determine whether the averages of achieving the goals, which is the institutionalization sub-dimension of the participants, showed a significant difference according to the legal structure of enterprises. As a result, p-value $(0.000<0.05)$ was statistically significant and the hypothesis ' $\mathrm{H} 2_{\mathrm{b}}$ : According to the legal structure of the enterprises studied, there is a difference in the institutionalization sub-dimensions to reach the goal.' was accepted. As a result of the Tukey test conducted in order to determine the source of the difference, it has been determined that the companies have joint stock companies, clubs, associations and other enterprises that create the difference according to their legal structure.

ANOVA analysis was performed to determine whether the averages of openness, which is the institutionalization sub-dimension of the participants, showed a significant difference according to the legal structure of the enterprises. As a result, the $\mathrm{p}$-value $(0.000<0.05)$ was found to be statistically significant and the hypothesis ' $\mathrm{H}_{2 \mathrm{c}}$ : According to the legal structure of the enterprises studied, there is a difference in the view of openness which is the institutionalization subdimension' was accepted. As a result of the Tukey test conducted to determine the source of the difference, it has been determined that, according to the legal 


\section{S.Annac Göv-H.M.Paksoy An Investigation on Effects of Certificates...}

structures of the enterprises, there are companies, clubs, associations and other enterprises that create the difference in openness.

H3: According to the task in the enterprise, there are differences in the view of institutionalization sub-dimensions.

H3 hypothesis which institutionalization sub-dimensions are determined and tested according to the personal status of institutions is given in Table 10.

Table 10. Relationship Between Personnel Position And Institutionalization Sub-Dimensions

\begin{tabular}{|c|c|c|c|c|c|c|}
\hline & & $\mathbf{N}$ & Med. & S.D. & $\mathbf{F}$ & Sig. \\
\hline \multirow{5}{*}{ Equality } & Owner & 27 & 2,85 & 0,20 & \multirow{5}{*}{14,61} & \multirow{5}{*}{0,000} \\
\hline & General Manager & 12 & 2,80 & 0,36 & & \\
\hline & Director of HRM & 38 & 2,08 & 0,67 & & \\
\hline & Pilot & 17 & 2,21 & 0,43 & & \\
\hline & Other & 18 & 2,71 & 0,35 & & \\
\hline \multirow{5}{*}{ Achieving a goal } & Owner & 27 & 2,38 & 0,49 & \multirow{5}{*}{3,93} & \multirow{5}{*}{0,005} \\
\hline & General Manager & 12 & 2,81 & 0,34 & & \\
\hline & Director of HRM & 38 & 2,51 & 0,36 & & \\
\hline & Pilot & 17 & 2,25 & 0,41 & & \\
\hline & Other & 18 & 2,35 & 0,44 & & \\
\hline \multirow{5}{*}{ Openness } & Owner & 27 & 2,67 & 0,00 & \multirow{5}{*}{8,82} & \multirow{5}{*}{0,000} \\
\hline & General Manager & 12 & 2,69 & 0,26 & & \\
\hline & Director of HRM & 38 & 2,34 & 0,48 & & \\
\hline & Pilot & 17 & 2,24 & 0,40 & & \\
\hline & Other & 18 & 2,80 & 0,41 & & \\
\hline
\end{tabular}

ANOVA analysis was carried out to determine whether the averages of equality scores, which are the institutionalization sub-dimensions of the participants, showed a significant difference according to the task variable in the enterprise. Since the p-value $(0.000<0.05)$ found in the result of the analysis was statistically significant, the hypothesis ' $\mathrm{H} 3_{\mathrm{a}}$ : There is a difference in the view of equality, which is the sub-dimension of institutionalization, according to the task in business' was accepted. As a result of the Tukey test conducted to determine the source of the difference, it has been determined that according to the task in the enterprise, the General Manager, HRD manager, owner and pilots who make the difference in equality.

ANOVA analysis was performed in order to determine whether there was a significant difference in the scores of the achieving goal points of the 
institutionalization sub-dimension of the participants according to the task variable in the enterprise. As the p-value $(0.005<0.05)$ found in the analysis was statistically significant, the hypothesis ' $\mathrm{H} 3_{\mathrm{b}}$ : There is a difference in the view of reaching the goal with institutionalization sub-dimension according to the task in the enterprise' was accepted. As a result of the Tukey test conducted to determine the source of the difference, it was determined that the owner, the general manager and the pilots were the factors that made the difference in the view of achieving a goal, according to the task in the enterprise.

ANOVA analysis was performed in order to determine whether the averages of the openness scores, which are the institutionalization sub-dimension of the participants, showed a significant difference according to the task variable in the enterprise. Since the p-value $(0.000<0.05)$ found in the result of the analysis is statistically significant, the hypothesis 'H3c: There is a difference in the view of openness which is the institutionalization sub-dimension according to the task in the enterprise' was accepted. As a result of the Tukey test conducted to determine the source of the difference, according to the task in the enterprise, it has been determined that the owner, HRM manager and pilots who make up the difference in the view of the openness.

\section{CONCLUSION}

Industrially, stepped to the aviation sector at the beginning of 1900, Turkey has shown a significant improvement in the developing world due to economic factors and technological factors. While all these developments were; issues such as aviation safety and airworthiness have been standardized to specific rules and conditions globally. Providing standards to have certificates has become mandatory for enterprises. For certification activities; while the General Directorate of Civil Aviation is a national authority; EASA and ICAO are an international level authorities. Certification rules of the competent authorities affect the institutional structure of the aviation companies operating in Turkey, directly or indirectly.

Businesses were influenced institutionally both during the preparation process and after certification. Based on this, we can gather the findings obtained from the survey study applied to aviation enterprises, in 2 groups. In the first group, the effects of the preparation process for the certificate acquisition on the institutional structures of the enterprises are presented. In the second group, the effects of the acquired certificates on the institutional structures of the enterprises have been revealed.

The effects evaluated in the first group are: 


\section{S.Annac Göv-H.M.Paksoy An Investigation on Effects of Certificates...}

Considering the number of employees, it is seen that there are large enterprises, mostly because they employ more than 250 employees. While the enterprises make their institutional structures, they usually do a SWOT analysis, but $24 \%$ of the enterprises operating in the civil aviation sector have done this analysis. Looking at this low rate, while creating the institutional structures of enterprises, only some of them show their strengths and weaknesses; it can be said that they evaluate opportunities and take measures against threats. Considering the effects of certification studies on the corporate identity of enterprises; it is seen that certificates affect the vision, mission, and strategies of the enterprises greatly. However, it has been found out that enterprises do not believe that the certification process should be planned.

When the results of the survey were evaluated, it was seen that coordination between the units was achieved while the license studies were carried out. While executing these studies, enterprises did not resort to outsourcing and benchmarking methods. While the companies were carrying out the certification studies, some of the participants stated that they had problems with SHGM and the other part stated that they did not have any problems.

More than half of the respondents stated that they coordinated with ICAO, EASA and DGCA in this process. In other words, ICAO, EASA and DGCA indirectly affected the institutional structures of enterprises. It can be said that the relations of the enterprises with their customers are independent of the certificate requirements. The certification requirements did not affect the social responsibility policies of the enterprises too much. Most of the aviation enterprises are not involved in social responsibility projects. Businesses, because they are institutions, have their own corporate culture. According to some participants; the corporate culture of aviation enterprises is affected by the certification requirements. Another part stated that the certificate requirements did not affect the corporate culture. So, indirectly, it can be said that the aviation rules affect the corporate culture. While the requirements of the certificates in the aviation sector partially affect the corporate governance dimensions of enterprises (fair, transparent, accountable, and responsible); institutionalization processes have accelerated considerably. According to the analysis of the survey; certificate requirements significantly affect the workflows between the units in the enterprise (personnel, financial affairs, marketing, public relations, quality control, etc.). All operations and operations in aviation enterprises are subject to certain rules. While $88.4 \%$ of enterprises in the sector employ human resources have regulated their job and job descriptions according to the certificate requirements. It is observed that the enterprises are largely dependent on the aviation rules when they form their in-house rules. 
Every step taken by the aviation companies has often found a place in the aviation legislation and is linked to a specific rule. Businesses can obtain certificates by complying with these rules. In this process, enterprises must establish quality management systems. When this research is analyzed; it has been seen that the process of obtaining a certificate facilitates the establishment of a quality management system for the enterprises.

Compliance with the rules in the aerospace sector, as in every sector, may require some costs. Certification requirements increase operating costs. According to aviation regulations, aviation companies have to prepare manuals. According to the research, these manuals greatly facilitate institutionalization.

Organizational conflicts can take place wherever there is a collective life. However, in the aviation sector, it was determined that there were no organizational conflicts among the employees in the certification process. This is due to the fact that the division of labor and the business requirements are clearly defined in the organization. After having the necessary certificates, the enterprises are influenced by some aspects.

The effects of the second group are as follows:

Aviation enterprises are believed to work more regularly and systematically after having the required certificate. As a result of the activities carried out, it has been greatly facilitated to provide supervision and control. Certificates are believed to reduce the rate of mistakes in businesses. Businesses do not believe that having a certificate makes it easier for the organization to achieve its goals. In other words, there is no link between having certificates and reaching the target. Business decisions are made at any time, sometimes, in this case, maybe blockages. According to the research, the decisions of certificates have not had any effect on the easing. Certificates contributed in part to employee participation. It is partly believed that budget and business plans become more open. The division of labor, which is a component of the management process in organizations, has begun to process much healthier during the certification process. One of the research findings is that there are many participants in the necessity to employ qualified personnel.

Efficiency is to provide the most output with minimum input. Certificates are believed to increase institutional productivity partly because certificates require hard and detailed requirements. This does not check out with the minimum input requirement.

Communication in organizations is an important component of the corporate structure and the management process. When the effect of aviation enterprises' having related certificates on institutional communication is examined, it has 


\section{S.Annac Göv-H.M.Paksoy An Investigation on Effects of Certificates...}

been determined that they have a positive effect. When all these findings are examined, it is concluded that legal regulations shaping the aviation sector and national and international certificates affect the institutional structures of enterprises.

It has been determined that there are differences in the point of view of the institutionalization factors of aviation enterprises. Businesses evaluate the institutionalization according to their fields of activity and their legal structures. In other words, the viewpoints of the airline companies and the aviation education enterprises on the institutionalization factors are different. The differences in the perspectives of enterprises stem from their legal structures. Since corporations have the advantage of being publicly traded and have an institutionalized structure, their point of view is different. Studies and arrangements may be made to improve the perspectives of other types of business in the aviation sector.

It is seen that the certificate conditions prevailing in the aviation sector do not affect the social responsibility awareness of the enterprises. In other words, enterprises do not develop social responsibility projects according to standards and certificates. Standards and certificates in the sector can be revised to improve the environmental and social responsibilities of enterprises. If legal arrangements are made in this direction, social responsibility projects such as clean fuel, green airport, clean environment, the unimpeded airport can become widespread.

The hypotheses were accepted as a result of factor analysis. In other words, according to the field of business; there are differences in the point of view of institutionalization sub-dimensions. According to the legal structure of the enterprises studied; there are differences in the view of institutionalization subdimensions. According to the task in the business; there are differences in the view of institutionalization sub-dimensions. There is a relationship between the institutionalization sub-dimensions and the certification (licensing) process subdimensions.

When all these findings are considered, it is concluded that the legal regulations, national and international standards and certificates that shape the aviation sector affect the institutional structures of the enterprises. In addition, due to bad experiences and reactive attitudes in the past 'Aviation rules were written in blood.' The jargon should be replaced by proactive practices.

Since there is not enough work in this field, the low number of reference is the limitation of the study.

\section{REFERENCES}

Ak, M. (1998). Firma/Markalarda kurumsal kimlik ve imaj. Reklam, Halkla 
İlişkiler ve Grafik Sanatları Dizisi.

Aktan, C. C. and Börü, D. (2007). Kurumsal sosyal sorumluluk. IGIAD Yayınları.

Balmer, J. M. T. and Soenen, G. B. (1998). A new approach to corporate identity management. International Centre for Corporate Identity Studies, University of Strathclyde.

Boseman, F. G., Phatak, A. V. and Schellenberger, R. E. (1989). Strategic management: text and cases. 2nd. Edition, John Willey-Sons, New York.

Brander Brown, J. and McDonnell, B. (1995). The balanced score-card: shortterm guest or long-term resident? International Journal of Contemporary Hospitality Management, 7(2/3), 7-11.

Bresser, R. and Millonig, K. (2003). Institutional capital: Competitive advantage in light of the new institutionalism in organization theory. Schmalenbach Business Review, 55.

Cronbach, L. J. (1950). Further evidence on response sets and test design. Educational and Psychological Measurement, 10(1), 3-31.

Dalay, İ., Coşkun, R. and Altunışık, R. (2002). Stratejik boyutuyla modern yönetim yaklaşımları. Beta Basım Yayım Dağıtım AŞ.

Deloitte (2007). Aile Şirketleri için Adım Adım Kurumsal Yönetim. Türkiye Kurumsal Yönetim Derneği ve Deloitte Ortak Yayını. http://www.tkyd.org/files/downloads/faaliyet_alanlari/yayinlarimiz/tkyd_ yayinlari/aile_sirketleri_icin_adim_adim_ky.pdf

Dillard, J. F., Rigsby, J. T. and Goodman, C. (2004). The making and remaking of organization context: duality and the institutionalization process. Accounting, Auditing \& Accountability Journal, 17(4), 506-542.

Dinçer, Ö. (1992). Stratejik yönetim ve işletme politikası. Marmara Üniversitesi İktisadi ve İdari Bilimler Fakültesi.

Dowling, G. R. (1993). Developing your company image into a corporate asset. Long Range Planning, 26(2), 101-109. 


\section{S.Annac Göv-H.M.Paksoy An Investigation on Effects of Certificates...}

Ganesh, S. R. (1980). Institution Building for Social and Organizational Change: An Appreciation. Organization Studies, 1(3), 209-227.

Goffee, R. and Jones, G. (2002). Kurum kültürü. Kapital Medya.

Greer, C. R. (2001). Strategy and human resources: a general managerial approach. Prentice-Hall, Upper Saddle River (NJ).

Hasselbladh, H. and Kallinikos, J. (2000). The project of rationalization: a critique and reappraisal of neo-institutionalism in organization studies. Organization Studies, 21(4), 697-720.

Hitt MA, Ireland R.D. and Hoskissoti, R. E. (1995). Strategic Management: Competitiveness and Globalization. NY. ISBN: 978-1-305-50214-7

İzzet, B. (2004). İletişim odaklı pazarlama. Mediacat Kitapları.

Jepperson, R. L. (1991). Institutions, institutional effects, and institutionalism. The New Institutionalism in Organizational Analysis, 6, 143-163.

Kaplan, R. S. and Norton, D. P. (2004). Strategy maps: Converting intangible assets into tangible outcomes. Harvard Business Press.

Kayacan, M. (2005). Anonim şirketlerin sosyal sorumluluklarl ve etik değerler. İSMMMO I. Uluslararası Muhasebe Denetimi Sempozyumu, Antalya, Www. Ismmmo. Org. Tr.

Kenaroğlu, Y. (2011). Hava araçlarının uçuşa elverişlilik sertifikasyonu. Mühendis ve Makina Dergisi, 52(614), 17.

Leskinen, L. A., Leskinen, P., Kurttila, M., Kangas, J. and Kajanus, M. (2006). Adapting modern strategic decision support tools in the participatory strategy process-a case study of a forest research station. Forest Policy and Economics, 8(3), 267-278.

Menteş, A. (2009). Kurumsal yönetişim ve Türkiye analizi. Derin Yayınları.

Moingeon, B. and Ramanantsoa, B. (1995). An identity study of firm mergers: the case of a French savings bank. Case Method Research and Application, 7, 253-260. 
Okay, A. (2000). Kurum kimligi, 2. Bask1. In Media Cat Kitaplar1.

Scott, W. R. (2013). Institutions and organizations: Ideas, interests, and identities. Sage Publications.

Sönmez, A. and Toksoy, A. (2011). Kurumsal yönetim ilkelerinin Türkiye’deki aile işletmelerine uygulanabilirliği. Maliye Finans Yazıları, 92, 51-90.

TDK. (1988). Türkçe Sözlük.Türk Dil Kurumu.

Thompson, A. A., \& Strickland, A. J. (1992). Strategic management: Concepts and cases. Irwin Professional Publishing.

Ülgen, H. and Mirze, S. K. (2007). İsletmelerde stratejik yönetim. Arıkan Basım Yayım Dağıtım.

Uzoğlu, S. (2001). Kurumsal kimlik, kurumsal kültür ve kurumsal imaj . Kurgu Anadolu Üniversitesi Illetişim Bilimleri Fakültesi Uluslararası Hakemli İletişim Dergisi , 18(18) , 337-353 .

Wilson, I. (1994). Strategic planning isn’t deadit changed. Long Range Planning, 27(4), 12-24.

Businessdictionary (2018, 10 April). http: www.businessdictionary.com 